\title{
Application of Failure Modes and Effects Analysis (FMEA) in Automated Spot Welding Process of an Automobile Industry: A Case Study
}

\author{
Hippalgaonkar Amrutha ${ }^{1}$, Joshi Ajinkya ${ }^{2}$, More Surabhi ${ }^{3}$ \\ ${ }^{1,2,3}$ K. K. Wagh Institute of Engineering Education and Research, Nashik. \\ 1 ammusworld@gmail.com \\ 2 ajinkya_j@rediffmail.com \\ 3 surabhimore26@gmail.com
}

\begin{abstract}
Automation in the manufacturing sector has become a subject of great interest nowadays and Spot welding through robotics has become a trend in the business market. Failure Modes and Effect Analysis (FMEA) process helps to reduce the errors and thereby improve the quality of the product being produced. The application of FMEA in this arena is a challenging task.
\end{abstract}

Through this study, an attempt has been made to identify and provide solutions to the challenges faced by a small scale local automobile company. The manual operations of spot welding in the organization were replaced by a robotic process. Although the speed of production increased, certain errors in the robotic spot welding process gave rise to quality issues. Errors occurring during the execution of the robotic spot welding process were identified and analysed by Cause and Effect diagram and FMEA method. During the study, ten $\mathrm{CO} 2$ and three spot welding failures were observed. Efforts were made to minimize the failures by assigning risk priority numbers to each failure and mistake proofing the failures. Results indicate that proper maintenance of fixture, safety sensor and robot teaching can avoid these errors and provide a quality product.

This activity has paved a path for the smooth implementation of FMEA in spot welding process by improving its effectiveness and customer centric products. To enhance quality and increase the speed of the manufacturing process, this cost effective technique can be extended to similar organizations with suitable modifications.

Keywords: FMEA process; Mistake proofing; Robotic, Spot welding; Automobile sector; Cause and Effect diagram.

\section{Introduction}

Robots have become a subject of great interest with which the world has done many miracles. Their applications in the manufacturing industry have created quality products and saved time. A robot is a software based solution designed to carry out repetitive processes or tasks that are usually carried out manually (Jovanović et al., 2018).

Automation through robots not only increases the overall working efficiency but also achieves high quality in the manufacturing of finished goods. However errors in the robotic process may give rise to quality issues. As such it is very necessary to identify and eliminate the errors in the robotic operations of spot welding.

FMEA is an approach to identify possible failures in a design, manufacturing, assembly, product or a service. Analysis can be carried out by employing the Ishikawa Cause and Effect diagram. In this method, failures are prioritized in accordance with their consequences, frequency and ease of detection. The main aim using this method is to eliminate / reduce failures based on priority. FMEA offers several benefits such as prevention of failures, identification of critical aspects of the process, design and control areas, continuous improvement and cost optimization. FMEA can be categorized as Design and Process FMEA.

In the past researchers have suggested that robotic errors can be avoided with the help of Failure Modes and Effects Analysis (Sutrisno and Lee, 2011; Dumitru and Cherciu, 2015; Sharma and Srivastava, 2018; Kulińska et al., 2018). The FMEA technique was introduced in the late 1940 's by the US military forces. In the 1960's it was used by the aerospace industry as a design methodology, with their obvious reliability and safety requirements. In the late 1970's, the Ford Motor Company introduced FMEA to the automotive industry for safety and regulatory consideration. They also used it to improve production and design. At present FMEA is widely used in manufacturing industries in various phases of the product life cycle. The technique is also used extensively in a variety of industries including semiconductor processing, food service, plastics, power plant, software, and healthcare (Sharma and Srivastava, 2018). FMEA also improves the quality of performance of operation by going to the root cause of the problem and providing various alternatives to solve this problem. A qualitative assessment of the error has to be done in order 
to ascertain the probability of occurrence of the error which identifies risks associated with it and sets appropriate corrective measures accordingly (Dumitru and Cherciu, 2015). This process provides the quality output by finding out the fault in operation and suggesting what action should be taken for removing the fault. The application of the FMEA should allow the reduction or elimination of gaps between manufacturing cycle times and the execution of orders (Kulińska et al., 2018).

This paper focuses on the application of FMEA in the field of robotic spot welding process. Spot welding automation through robots is rapidly engulfing the market. The company under the study employs spot welding and $\mathrm{CO}_{2}$ welding. These two processes are briefly discussed as follows:

Spot welding: Spot Welding is a process in which contacting metal surface points are joined by the heat obtained from resistance to electric current. Work pieces are held together under pressure exerted by electrodes. During the resistance welding process, the welding electrodes are exposed to severe heat and pressure. To restore the shape of the electrodes an automatic tip-dresser is used.

The spot welding process carried out in the company is shown in figure 1 . Some movements that are awkward for an operator, such as positioning the welding gun upside down, are easily performed with the help of this robot.

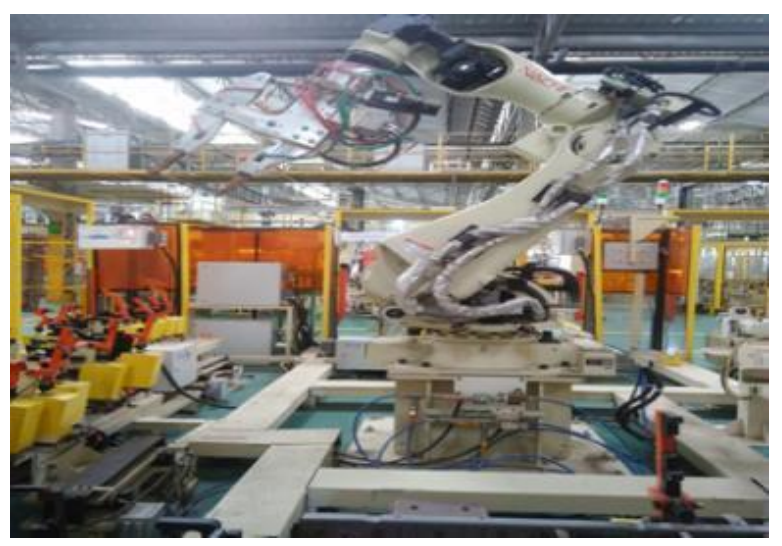

Fig. 1: Spot welding robot

$\mathrm{CO}_{2}$ welding: Carbon Dioxide $\left(\mathrm{CO}_{2}\right)$ is the most common of the reactive gases used in MIG (Metal Inert Gas) welding and the only one that can be used in its pure form without the addition of an inert gas. $\mathrm{CO}_{2}$ is also the least expensive of the common shielding gases, making an attractive choice when material costs are the main priority.

In the present study, manual welding operations in a small scale automobile company were replaced by a robotic process. After implementation of the robotic process, it was observed that the robotic operation provided much superior quality as compared to the manual operation. However, certain errors were observed in the robotic operations which lead to quality issues and implementation difficulties. These errors created quality issues for the organization. The errors were identified and an FMEA process was designed to prevent their reoccurrence and achieve the desired quality standards.

Although robotic processes enable faster, easier and low cost operations, the structure may become complex and challenging (Hofmann et al., 2020). It therefore depends on the organization whether to implement the robotic spot welding process on a temporary or permanent basis. This study will serve as a guideline for the aspiring small scale organizations to automate their manufacturing process.

\section{Literature Review}

Any manufacturing company focuses on producing quality products and for that it works rigorously on different tools to be implemented for better outcome. FMEA is one of the tools that help organizations to understand and achieve quality results. So far several approaches and applications of FMEA have been developed. Rakesh, et al. (2013) conducted a study to analyze the role of FMEA for reducing breakdowns in the company. The authors have explained the process of FMEA in an automatic plastic welding machine. In this study, the detection value was assigned to the failure mode and the risk priority number value was calculated. FMEA analysis helps in reducing down time of the machine by improving its reliability.

FMEA acts as a reliability tool, where risk based maintenance techniques have proved to be a cost effective tool in maintenance plans. The importance of reliability depends on certain factors which invariably influence the engineering components. In a study it has been observed that process failure mode and effect analysis has a major drawback especially when integrated with lean production in an automotive industry (Afolalu et al., 2018). Analysis of FMEA reliability improvements was studied in various fields such as wind turbine equipment, manufacturing systems, medical industry and robots. The outcome of the survey pointed out that reliability engineering paves for quality centres around the expenses of failures caused by system downtime, cost of extras, repair gear, work force and cost of guarantee claims.

Implementation of FMEA is a continuous quality improvement process too. Doshi and Desai, (2016) implemented FMEA with the help of Cross Functional Team (CFT) to identify the potential failure modes and effects that affect the continuous quality improvement. The outcome of the study at four companies has revealed that there is a scope of improvement in the manufacturing process. Implementation of those improvement points 
shows the definite signs of continuous improvement of the quality of process and product as well. There are key performance indicators to be considered to achieve these continuous quality improvements; such KPIs can be cost of quality, rejection at the final inspection stage, and customer satisfaction.

FMEA is a cyclic process and there is a need for continuous assessment. Subriadi and Najwa (2020) proposed a differentiation between traditional and improved FMEA which can pave the path for the most optimal solutions. In his research, the gap reflects the risk which was dealt earlier. An in-depth analysis of the process and situation was carried out to investigate the gap and implement the improved FMEA. An example of this situation has been depicted by implementing it in information technology risk assessment. The design of FMEA documents was modified by categorizing the failure effects into three parts, namely the services / operational, media attention, and regulation. Improved FMEA consists of four main stages namely determination of the risk assessment requirements, risk identification, risk analysis, and evaluation. Two action researches were carried out to identify the gap. First research proved that traditional FMEA produced inconsistent values. However, second research proved that the FMEA weaknesses identified could be minimized. This shows that FMEA is a continuous and cyclic process predicting the gaps and further improving the performance.

The optimal solution for the failures through FMEA has widened its application in various industries (Dastjerdi, et al. 2017; Kumar and Mondloi, 2018). Some of the applications have been discussed here. Helia and Wijaya, (2017) in their study have extended the application of FMEA to identify Iron Sand rejection and losses in the cement industry. The authors have proposed improvements on how to reduce this failure rate and to determine the most dominant activity for the cause of rejection and losses with iron sand. It was suggested to re-review the contract clause with its vendor. A review of the contract clause could help in increasing the penalty sanctions in violation of the contract clause and accelerate the due date.

An application of FMEA to medical robotic systems was undertaken by Silva and Seriani (2018). A foreseeable potential defect along with their causes and effects for a robotic safety were identified. To assess the safety risks, FMEA was applied as a risk assessment tool to mitigate or eliminate risk. An appropriate use of safety methods analysis reduced the risk of injury therefore it was recommended to be engaged at an early stage of development of a collaborative assembly. Researchers have recommended two safety methods to improve the safety control in the company namely Hazard and Operability Analysis.
FMEA can help make adequate decisions and identify potentials in the design of actuating elements for wearable robotics, while putting the user needs at the center of the design process. An application of FMEA in robotics enhances the decision making based on the interdependence between design parameters and the device requirements, as well as an early identification of several functional risks (García, et al., 2019).

This paper extends the application of FMEA in the field of spot welding process at Automated (Robot) Car Manufacturing Industry whilst emphasising on performance improvement and simple implementation methodology for quality output. During this study, FMEA technique was implemented to analyse the failures. Results indicate that this technique has proved effective in minimizing the errors and increasing the efficiency. The reliability assessment of robots is essential for continuous improvement in their performance.

\section{Methodology}

The company under consideration manufactures inner body parts for the cars. These sheet metal parts are shown in figure 2. Each part requires spot welding for assembling the job. As discussed earlier, the task of spot welding of the metal sheets was carried out manually. The process is now carried out with the help of robots. The welding process / operation of making the parts in the company's project are operated by spot welding robots only. The company has a total of seven cells for the project where six cells are assigned for spot welding and one for $\mathrm{CO}_{2}$ spot welding. Each cell contains two robots and multiple fixtures. Fixtures have the sensors which sense the proper position of metal parts during the welding process. Mimic model is used for getting the overview of the position of the welding spot on a particular part. Safety sensors are available to the cell, which protects the employees when the robot is in working condition. To identify the failures in the process, the process of FMEA implementation in the company has been discussed below.

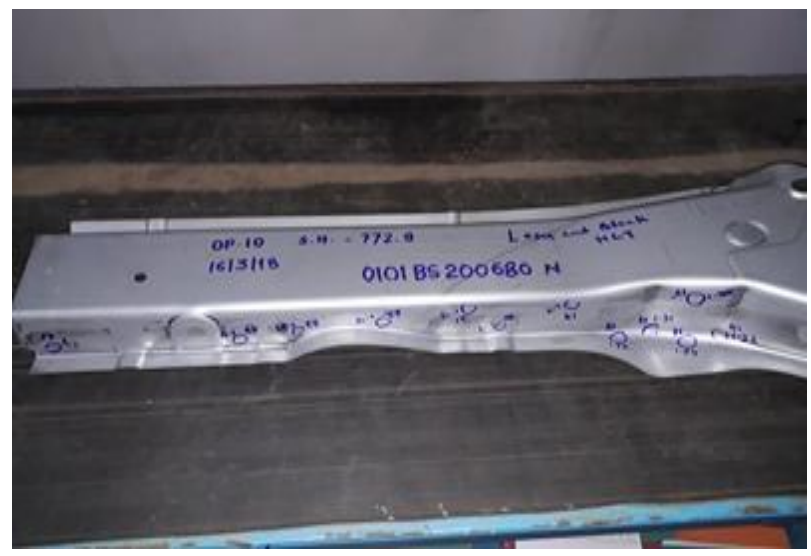

Fig. 2: Sheet metal parts of cars 


\subsection{Cause and Effect Diagram}

The Cause and Effect diagram is used to identify, explore, and graphically display in increasing detail all the possible causes related to a problem or condition to discover its root causes. Through observations and discussion with the employees of the company, the Cause and Effect / Ishikawa / Fish-bone diagram was derived and is shown in figure 3 .

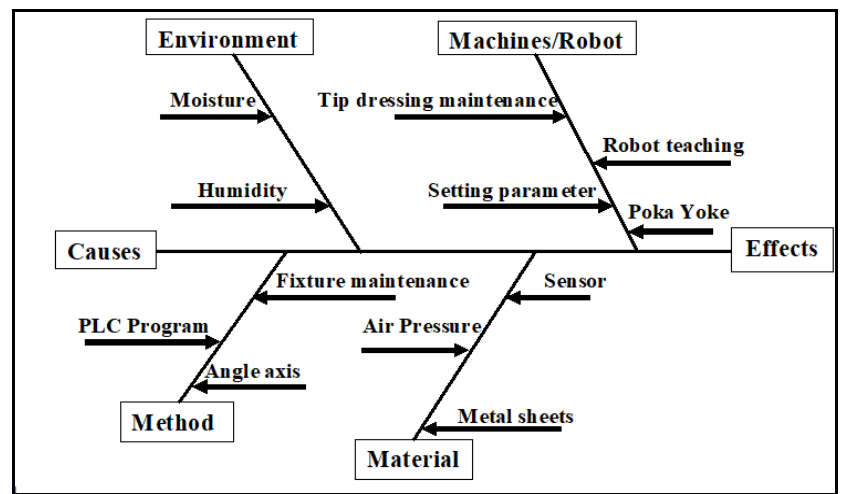

Fig. 3: Cause and Effect diagram

The above Cause and effect diagram is explained briefly as follows:

a. Machine / Robot:

This includes all machines under the process, they are robots, equipment and tools necessary to accomplish the task. Following areas of failures were identified under machines.

1. Robot teaching: Proper robot teaching was not followed.

2. Tip dressing maintenance: Tip dressing maintenance is required in order to avoid the spot burr and weak spot.

3. Setting parameter: Proper parameters should be set by operator for proper working of the spot welding.

b. Method:

This defines how the process is performed and all requirements needed for doing it. The possible areas of failures under methods are:

1. PLC Programming: Provide correct programming to robot for proper execution of operation of spot welding

2. Fixture maintenance: Fixture sensor maintenance is required to sense the correct part position in the spot welding process.

3. Angle axis: The robot should rotate in all directions to achieve the quality output. c. Material:

Raw material, purchased parts and sub-assemblies that feed into the finished product are considered here. The observed failures in this area are:

1. Sensor: Proper sensing function was not found during the operations.

2. Current: Proper current supply was not provided during the process.

3. Air pressure: Appropriate air pressure required for quality spot welding.

4. Metal sheet: Maintain the quality of raw material for quality finished goods.

d. Environment:

The conditions that influence the process such as time, temperature, humidity and cleanliness are considered under the environment. For the sake of convenience, these have been grouped under moisture and humidity.

Moisture and humidity: Moisture and humidity during the process were observed that can lead to the atmosphere corrosion on the surface of the metal.

\subsection{Failure mode identification based on Machine/ Robot Causes:}

Amongst the method, material, environment and machines/ robot, the most significant causes considered under the study are Machine/ Robot. Following are the failure modes identified under Machine/ Robots:

1. Tip dressing Maintenance: The failure modes detected due to tip dressing are: weak spot, spot burr, spot should be round.

2. Robot Teaching: Under robot teaching, recognised failure modes are: spot missing, Spot position is not as per drawing.

3. Setting Parameter: Deep spot and Spot burn are the failure modes observed under setting parameter.

4. Poka Yoke: Required total number of parts, No wrong assembly and Hole missing are the failures under Poka Yoke that need to be considered to improve spot welding process.

\subsection{FMEA in Spot Welding and $\mathrm{CO}_{2}$ Welding:}

It was observed that there were ten failure modes found in spot welding related to Machine/ Robot causes derived from the cause and effect diagram. Similarly, three failure modes in $\mathrm{CO}_{2}$ welding were identified. The robotic spot and $\mathrm{CO}_{2}$ welding process failure modes with the prevention control and RPN number have been derived.

The ten failure modes observed under the robotic spot welding process are shown in table 1: 
Table 1: Failure modes under spot welding

\begin{tabular}{|c|c|c|c|}
\hline Failure Mode & Causes & Prevention & Effects \\
\hline $\begin{array}{l}\text { Spot missing: Position of nuts was not } \\
\text { in the proper place as per the diagram } \\
\text { provided in the project. }\end{array}$ & $\begin{array}{l}\text { As the robot teaching was not proper, } \\
\text { the failure was identified. }\end{array}$ & $\begin{array}{l}\text { Proper robot teaching with } \\
\text { validation is required. }\end{array}$ & $\begin{array}{l}\text { If the problem is not resolved, it } \\
\text { may create problems in the next } \\
\text { operation of spot welding. }\end{array}$ \\
\hline $\begin{array}{l}\text { Weak spot: Some space remains in } \\
\text { joining of two parts i.e. gap between } \\
\text { the spots can create defective products. }\end{array}$ & $\begin{array}{l}\text { Tip dressing is not done properly, } \\
\text { fluctuation in current is observed, } \\
\text { current supply is not proper, less force } \\
\text { is applied and excess gap between two } \\
\text { matting components is found. }\end{array}$ & $\begin{array}{l}\text { Carbon testing should be done at } \\
\text { the starting of shift. After every } 100 \\
\text { spot welding, activities such as } \\
\text { process qualification, setting of } \\
\text { online parameter display, and } \\
\text { component and fixture verification } \\
\text { on CMM (coordinate measuring } \\
\text { machine) are required. }\end{array}$ & $\begin{array}{l}\text { If corrective measures are not } \\
\text { taken, it may break the part in the } \\
\text { next step of operation. The body } \\
\text { becomes noisy at the customer } \\
\text { end. }\end{array}$ \\
\hline $\begin{array}{l}\text { Spot Burr: Spot welding on part } \\
\text { should be free from burr. }\end{array}$ & $\begin{array}{l}\text { Tip dressing should work properly, } \\
\text { high current flow at the welding spot, } \\
\text { more welding time is observed, there } \\
\text { is a gap between parts as the part } \\
\text { provided for spot welding was not } \\
\text { proper. }\end{array}$ & $\begin{array}{l}\text { Same precautions as in case of } \\
\text { weak spots need to be undertaken. } \\
\text { Carbon testing to be done at the } \\
\text { starting of shift. After every } 100 \\
\text { spot welding, activities such as } \\
\text { process qualification, setting of } \\
\text { online parameter display, } \\
\text { component and fixture verification } \\
\text { on CMM (coordinate measuring } \\
\text { machine) should be undertaken. }\end{array}$ & $\begin{array}{l}\text { Assembly of parts will not be done } \\
\text { properly. If unchecked, this may } \\
\text { break the part during the next } \\
\text { operation. The body may become } \\
\text { noisy at the customer end. }\end{array}$ \\
\hline $\begin{array}{l}\text { Spot Position not as per drawing: } \\
\text { Spot position should be as per the } \\
\text { drawing. }\end{array}$ & Robot teaching is not proper. & $\begin{array}{l}\text { Proper robot teaching with } \\
\text { validation is required. }\end{array}$ & $\begin{array}{l}\text { Assembly of parts will not be done } \\
\text { properly. Noisy body at the } \\
\text { customer end. }\end{array}$ \\
\hline $\begin{array}{l}\text { Spot Burn: Spot burns observed } \\
\text { during the process. }\end{array}$ & $\begin{array}{l}\text { High current, more welding time, high } \\
\text { force. }\end{array}$ & $\begin{array}{l}\text { Can be prevented by process } \\
\text { qualification and setting online } \\
\text { parameter display. }\end{array}$ & $\begin{array}{l}\text { At the end user vehicle strength } \\
\text { gets reduced, vibration and noise } \\
\text { will be increased at customer's } \\
\text { end. This is also likely to break the } \\
\text { part during the next operation. }\end{array}$ \\
\hline $\begin{array}{l}\text { Deep Spot: Deep spots observed } \\
\text { during welding. }\end{array}$ & $\begin{array}{l}\text { This type of failure occurs if the tip } \\
\text { alignment is not proper, more welding } \\
\text { time has been observed or high force } \\
\text { is applied by robots during welding. }\end{array}$ & $\begin{array}{l}\text { Carbon testing should be done at } \\
\text { the starting of shift and after every } \\
100 \text { spot welding, process } \\
\text { qualification is required, setting } \\
\text { parameter display online. }\end{array}$ & $\begin{array}{l}\text { End user product's poor } \\
\text { appearance. Next operation may } \\
\text { break the part. }\end{array}$ \\
\hline $\begin{array}{l}\text { Spot should be round (diameter } 4 \text { to } \\
6 \mathbf{m m} \text { ): Spot dimension should be } \\
\text { between } 4 \mathrm{~mm} \text { to } 6 \mathrm{~mm} \text {. (Oversize, } \\
\text { undersize spot) }\end{array}$ & $\begin{array}{l}\text { Tip dressing is not done properly, Tip } \\
\text { alignment is not proper. }\end{array}$ & $\begin{array}{l}\text { Tip dressing after } 100 \text { spots, carbon } \\
\text { test at starting of shift and after } 100 \\
\text { spots is recommended. }\end{array}$ & $\begin{array}{l}\text { Will result in vibration and noise } \\
\text { in the body at the user end. }\end{array}$ \\
\hline $\begin{array}{l}\text { Total number of parts: All parts } \\
\text { related to the process should be } \\
\text { available in operation of welding. }\end{array}$ & $\begin{array}{l}\text { No poka yoke in the fixture, Poka- } \\
\text { yoke not working. }\end{array}$ & $\begin{array}{l}\text { Poka-yoke in fixture, Poka-yoke } \\
\text { verification by defective sample }\end{array}$ & May lead to assembly problems. \\
\hline $\begin{array}{l}\text { No Wrong Assembly: Wrong } \\
\text { assembly of parts creates defective } \\
\text { products. Child parts may have been } \\
\text { wrongly assembled. }\end{array}$ & Poka-yoke not working. & $\begin{array}{l}\text { Poka-yoke verification by } \\
\text { defective sample. }\end{array}$ & Fitment Problem. \\
\hline $\begin{array}{l}\text { Hole Missing: During spot welding, } \\
\text { the hole to be welded can be wrongly } \\
\text { positioned. }\end{array}$ & Poka-yoke not working. & $\begin{array}{l}\text { Poka-yoke verification by defective } \\
\text { sample. }\end{array}$ & Fitment Problem. \\
\hline
\end{tabular}


The three failure modes observed in the $\mathrm{CO}_{2}$ spot welding are shown in table 2:

Table 2: Failure modes under $\mathrm{CO}_{2}$ spot welding

\begin{tabular}{l|l|l}
\hline \multicolumn{1}{c}{ Failure Mode } & \multicolumn{1}{c}{ Causes } & \multicolumn{1}{c}{ Prevention } \\
\hline $\begin{array}{l}\text { Spot missing: Position of nuts should } \\
\text { be in the proper place as per diagram. }\end{array}$ & Teaching is not proper. & $\begin{array}{l}\text { Proper robot teaching with } \\
\text { validation. }\end{array}$ \\
\hline $\begin{array}{l}\text { Spot Burr: Spot welding on part } \\
\text { should be free from burr. }\end{array}$ & $\begin{array}{l}\text { Tip dressing not working properly, } \\
\text { high Current, more weld time, gap } \\
\text { between parts: as part is not proper. }\end{array}$ & $\begin{array}{l}\text { Carbon test at starting of shift and } \\
\text { after 100 spots, component and } \\
\text { Fixture Verification on CMM. } \\
\text { operation of spot welding }\end{array}$ \\
\hline $\begin{array}{l}\text { Weak spot: Some space remains in } \\
\text { joining of two parts i.e. gap between } \\
\text { the spot. }\end{array}$ & $\begin{array}{l}\text { Less current, less force, excess gap } \\
\text { between two matting components }\end{array}$ & $\begin{array}{l}\text { Setting Parameter display on line, } \\
\text { component and fixture verification } \\
\text { on CMM. }\end{array}$ \\
\hline
\end{tabular}

\section{Results and Discussion}

The company has started automation of the process through robots and by the application of FMEA as discussed above, the failure modes were found through cause and effect diagram. Prioritizing these failures is necessary to know the failure mode which is more risky and needs to be emphasised by the company. The results of RPN calculations and their ranking are discussed below.

\subsection{Priority table with respect to RPN (Risk Priority Number) Calculations: -}

RPN (Risk Priority Number was calculated for both the welding processes through the observations, interviewing the operators, quality manager and noting the occurrence of failures. The formula for RPN Calculations is:

$$
\mathrm{RPN}=\text { Severity } * \text { Occurrences } * \text { Detection }
$$

Based on the RPN calculations for each failure, priority of failure is decided which helps the management to concentrate on most risky failures and take decisions accordingly.

\section{Spot welding:}

The RPN calculations for the failure modes in spot welding are shown in table 3 .

Table 3: RPN Calculations for Spot Welding

\begin{tabular}{cccc}
\hline Failure Mode & Potential cause (s) & RPN & Priority \\
\hline Spot missing & Teaching is not proper & 90 & 6 \\
\hline
\end{tabular}

\begin{tabular}{|c|c|c|c|}
\hline \multirow{4}{*}{ Weak spot } & $\begin{array}{l}\text { Tip dressing is not done } \\
\text { properly }\end{array}$ & 84 & 7 \\
\hline & Less current & 21 & 14 \\
\hline & Less force & 60 & 9 \\
\hline & $\begin{array}{l}\text { Excess gap between two } \\
\text { matting components }\end{array}$ & 28 & 13 \\
\hline \multirow{4}{*}{ Spot Burr } & $\begin{array}{c}\text { Tip dressing is not working } \\
\text { properly }\end{array}$ & 75 & 8 \\
\hline & High Current & 108 & 4 \\
\hline & More Weld Time & 60 & 9 \\
\hline & $\begin{array}{l}\text { Gap between parts due to } \\
\text { faulty parts }\end{array}$ & 50 & 10 \\
\hline \multirow[t]{2}{*}{$\begin{array}{l}\text { Spot position as } \\
\text { per drawing }\end{array}$} & Robot teaching not proper & 84 & 7 \\
\hline & High Current & 40 & 12 \\
\hline \multirow[t]{2}{*}{ Spot burn } & More Weld Time & 90 & 6 \\
\hline & High Force & 75 & 8 \\
\hline \multirow{3}{*}{ Deep Spot } & Tip alignment not ok & 108 & 4 \\
\hline & More Weld Time & 200 & 1 \\
\hline & High Force & 120 & 3 \\
\hline \multirow{2}{*}{$\begin{array}{l}\text { Spot should be } \\
\text { round (Dim. } 4 \text { to } \\
6 \mathrm{~mm})\end{array}$} & $\begin{array}{l}\text { Tip dressing not done } \\
\text { properly. }\end{array}$ & 144 & 2 \\
\hline & Tip alignment not ok & 75 & 8 \\
\hline
\end{tabular}




\begin{tabular}{cccc}
\hline \multirow{2}{*}{$\begin{array}{c}\text { Total number of } \\
\text { parts }\end{array}$} & No poka yoke in fixture & 120 & 3 \\
\cline { 2 - 4 } & Poka-yoke not working & 60 & 9 \\
\hline $\begin{array}{c}\text { No Wrong } \\
\text { Assembly }\end{array}$ & Poka-yoke not working & 45 & 11 \\
\hline Hole Missing & Poka-yoke not working & 100 & 5 \\
\hline
\end{tabular}

In robotic spot welding, the cause having the first priority (RPN-200) should be executed first to avoid the problem i.e. if a deep spot is found then welding time will be more. The second priority is tip dressing (RPN-144), which if not done properly may result in error. In spot welding, the diameter should be around 4 to $6 \mathrm{~mm}$. High force in deep spots and Poka Yoke in fixtures is considered as the third priority (RPN-120). Fourth priority (RPN-108) is assigned to the high current during the operation in spot burr and tip alignment resulting in a deep spot. Then the Company needs to focus on fifth priority (RPN-100) i.e. Poka Yoke is not working.

Sixth priority is related to the teaching (RPN-90) of Robot. If teaching is not proper, a missing spot will occur and additional welding time will result in spot burn. Seventh priority is the tip dressing (RPN-84). Improper tip dressing results in weak spots and robot teaching is not proper for spot position as per drawing. The eighth priority is assigned to Tip dressing, Spot Burr and high force in spot burn and tip alignment (RPN-75). The ninth priority is to have less force in weak spots and more weld time in spot burr and Poka Yoke is not working in total number of parts (RPN-60). The tenth priority relates to the gap between parts due to faulty part at spot burr (RPN-50).

\section{$\mathrm{CO}_{2}$ Spot welding:}

The RPN calculations for $\mathrm{CO}_{2}$ Spot Welding are shown in table 4.

Table 4: RPN Calculations for $\mathrm{CO}_{2}$ Spot Welding

\begin{tabular}{cccc}
\hline $\begin{array}{c}\text { Failure } \\
\text { Mode }\end{array}$ & Potential Cause (s) & RPN & Priority \\
\hline $\begin{array}{c}\text { Spot } \\
\text { missing }\end{array}$ & $\begin{array}{c}\text { Teaching is not } \\
\text { proper }\end{array}$ & 28 & 5 \\
\hline & $\begin{array}{c}\text { Tip dressing not } \\
\text { working properly }\end{array}$ & 40 & 3 \\
\cline { 2 - 4 } $\begin{array}{c}\text { Spot } \\
\text { Burr }\end{array}$ & High Current & 70 & 1 \\
\cline { 2 - 4 } & More Weld Time & 40 & 3 \\
\hline $\begin{array}{c}\text { Gap between parts } \\
\text { due to faultyparts. }\end{array}$ & 50 & 2 \\
\hline Spot & Less current & 21 & 6 \\
\hline
\end{tabular}

Excess gap between
two matting

In $\mathrm{CO}_{2}$ welding, the cause having first priority (RPN70) should be executed first to avoid the problem of high current in no spot burr. Then the second priority is the gap between parts due to faulty parts in spot burr (RPN-50). Third priority is tip dressing and spot burr due to more weld time (RPN-40). The fourth priority is to have less force in order to avoid weak spots (RPN-30). Fifth priority is that the robot teaching is not done properly indicating spot missing during operation and excess gap between two mating components due to which weak spots are observed (RPN-28). Sixth priority is to the high current resulting in the weak spot (RPN-21).

\section{Findings:}

Automation in spot welding and $\mathrm{CO}_{2}$ welding improves the speed and quality of process. Robotic spot welding provides higher efficiency as compared to manually welding of parts. It has been observed in manual operations that the cycle time was 8 hours for completion of 10 jobs while in robotic operations the cycle time was 8 hours for completion of 70 jobs. The efficiency can thus be judged in terms of speed and quality of the product and elimination of breakdown in the production process. The automated process requires semi-skilled manpower as compared to manual operations. In the event of any problem, robots halt the process / working immediately. However, robotic operations are not free from failures. Design of FMEA is essential to increase the efficiency and to prioritize the failures and prevent their reoccurrence.

A robotic spot welding FMEA process was designed to identify the errors during the operation. This was done by investigating the causes of the errors and prioritizing them through observations and questions to the quality section. A total of ten failure modes in spot welding and three failure modes in $\mathrm{CO}_{2}$ welding were observed. By solving these problems, based on their priority, robotic operations can run more smoothly. The study has shown how FMEA can be easily employed in spot welding robotic operations in a manufacturing industry.

\section{Suggestions:}

A few suggestions are hereby provided for the smooth operation of robots based on the identification of failures:

Fixture sensor maintenance: Fixture sensor is an essential part for spot welding which senses the proper position of the part and then allow for spot welding. The maintenance of the fixture sensor has to be done weekly.

Checking setting parameters: For efficient spot welding process, proper setting parameters such as adequate 
current flow and the impact force have to be checked consistently by the operator.

Robot teaching maintenance: Most of the error occurs because robot teaching is not proper. It is suggested that robot programming requires maintenance weekly.

Safety sensor maintenance: Safety sensors play an important role in robotic operation which protects employees while the robot is in the working process. Maintenance of safety sensors is required regularly for the safety of employees.

\section{Conclusion}

FMEA process identifies the error and provides the control of the variables to solve that error. It helps to reduce the error and provides a solution for achieving the quality process with high quality output. Maintenance of fixture sensors is necessary to avoid most of the failures in spot $/ \mathrm{CO}_{2}$ welding. A daily check-up of the robotic spot welding operations and continual maintenance is recommended. Although the cost of investment in robotic operation is more as compared to manual operations, the results of return on investment are much greater. Companies should avoid thinking of it as a cumbersome process rather it's an easy way of designing and implementing FMEA to a process which paves for quality assurance.

Besides understanding the overall robotic operation of spot welding and $\mathrm{CO}_{2}$ welding, the aim of the study was to identify errors occurring during the execution of a process. It was observed that although automation provides a high quality process, it also resulted in some errors. FMEA was found to be helpful in reducing errors occurring in the automated robotic operation.

As it is said 'Failure is the stepping stone to success.' Failures were observed in robotic operation and working on the failures ultimately led to success. Every manufacturing or service sector faces some or the other problem. In order to avoid problems, it is advisable that the manufacturing or service sectors should implement the cost effective FMEA process. An approach towards identifying minute details of the causes of errors and their effects is perhaps the best way to address the quality issues. FMEA may be adopted as one of the best practices by different industries.

Though robots will rule the world in future, manpower will be inevitable at any instance. Based on the results, authors strongly recommend further research by implementation of the FMEA process in different spot welding companies.

\section{References}

Dumitru, V. and Cherciu, M. (2015), Application of the FMEA Concept to Medical Robotic System, Advanced Engineering Forum, 13, pp. 324-331.

Hofmann, P., Samp, C. and Urbach, N. (2020), Robotic Process Automation, Electronic Markets, 30(1), pp. 99106.

Kulińska, E., Odlanicka-Poczobutt, M. and Kulińska, K. (2018), Diagnosis of Operational Malfunctions and Failures by the FMEA Method in the Industrial Robots Sector, Research in Logistics and Production, 8(1), pp. 523. DOI: $10.21008 / \mathrm{j} .2083-4950.2018 .8 .1 .1$

Sharma, K. and Srivastava, S. (2018), Failure Mode and Effect Analysis (FMEA) Implementation: A Literature Review, Journal of Advanced Research in Aeronautics and Space Science, 5(1-2), pp. 1-17.

Jovanovic, S. Z., Duric, J. S. and Sibalija, T.V. (2018), Robotic Process Automation: Overview and Opportunities, International Journal of Advanced Quality, 46(3-4), pp. 34-39.

Sutrisno, A. and Lee, T. (2011), Service reliability assessment using failure mode and effect analysis (FMEA): survey and opportunity roadmap, International Journal of Engineering, Science and Technology, 3(7), pp. 25-38.

Doshi, J. and Desai, D. (2016), Application of failure mode \& effect analysis (FMEA) for continuous quality improvement - multiple case studies in automobile SMEs, International Journal for Quality Research, 11(2), pp. 345-360. DOI: 10.18421/IJQR11.02-07

Rakesh, R., Jos, B. C., and Mathew, G. (2013), FMEA analysis for reducing breakdowns of a subsystem in the life care product manufacturing industry, International Journal of Engineering Science and Innovative Technology, 2(2), pp. 218-225.

Afolalu, S. A., Salawu, E. Y., Oluyemi, K., Ayuba, S. U., Ihebom, I. V. and Elewa, R. R. (2018), Failure Mode and Effect Analysis a Tool for Reliability Evaluation: Review, European Journal of Engineering Research and Science, 3(4), pp. 65-68. DOI: 10.24018/ejers.2018.3.4.636

Dastjerdi, H. A., Khorasani, E., Yarmohammadian, M. H. and Ahmadzade, M. S. (2017), Evaluating the application of failure mode and effects analysis technique in hospital wards: a systematic review,Journal of Injury and Violence Research,9(1), pp. 51-60. DOI: 10.5249/jivr.v9i1.794

Subriadi, A. P. and Najwa, N. F. (2020), The consistency analysis of failure mode and effect analysis (FMEA) in information technology risk assessment,Heliyon, $\quad 6(1), \quad$ pp. 1-12. DOI: 10.1016/j.heliyon.2020.e03161

Helia, V. N. and Wijaya, W. N. (2017), Failure Mode and Effect Analysis (FMEA) Applications to Identify Iron Sand Reject and Losses in Cement Industry: A Case Study,5th International Conference on Manufacturing, Optimization, Industrial and Material Engineering, IOP 
Conference Series: Materials Science and Engineering, 215(1):012039. DOI: 10.1088/1757-899X/215/1/012039

Kumar, R. and Mondloi, R. K. (2018), Failure Mode and Effect Analysis of Petrol Engine of Car,International Journal of Science and Research, 7(6), 180-183. DOI: 10.21275/ART20182731

Josiah, A. K., Keraita, J. N. and Muchiri, P. N. (2018), Failure Mode Identification And Prioritization Using FMEA- A Case Study Of Corn Milling Industry, IOSR Journal of Mechanical and Civil Engineering, 15(2), Ver. III, pp. 21-28.
Silva J. and Seriani S. (2018), Collaborative Robots in Manufacturing applications safety and Ergonomic Approach, Proceedings of 131st ISERD International Conference, Chicago, USA, pp. 50-55.

García, P. L., Crispel, S., Verstraten, T., Saerens, E., Convens, B., Vanderborght, B. and Lefeber, D. (2019), Failure Mode and Effect Analysis (FMEA)-Driven Design of a Planetary Gearbox for Active Wearable Robotics, Proceedings of the 4th International Symposium on Wearable Robotics, WeRob 2018, Biosysrob, 22, pp. 460464. DOI: 10.1007/978-3-030-01887-0_89 